\title{
Pengaruh Perbedaan Ketinggian Tempat Terhadap Capaian Hasil Inseminasi Buatan Pada Kambing Peranakan Ettawa
}

\author{
Setyo Utomo \\ Program Studi Peternakan, Fakultas Agroindustri, Universitas Mercu Buana Yogyakarta \\ Jl. Wates Km 10 Yogyakarta, 55753
}

\begin{abstract}
ABSTRAK
Penelitian ini dilaksanakan untuk mengkaji kinerja reproduksi dan capaian hasil IB kambing PE yang dipelihara di wilayah pantai mewakili dataran rendah dan wilayah pegunungan mewakili dataran tinggi. Penelitian menggunakan metoda survey di dua wilayah desa dengan populasi kambing PE terbanyak. Untuk wilayah dataran rendah dipilih wilayah desa Karangwuni sedangkan untuk wilayah pegunungan dipilih desa Sidomulyo. Hasil penelitian menunjukan bahwa untuk wilayah pantai vs pegunungan adalah sbb; Kinerja reproduksi pantai vs pegunungan; umur pertama estrus (10 vs 9,3 bl), umur pertama kawin (13,2 vs 12,5 bl), Cara kawin 100\% alam, PPM (4,2 vs 4,6 bulan), S/C (1,5 vs 1,6$)$, pemahaman betina bunting; anestrus pasca IB (85,7 vs $22,2 \%)$, perut turun $(14,3$ vs $0,00)$, kondisi ambing $(0,00$ vs $77,8 \%)$. Capaian hasil IB (37,5 vs $40 \%)$. Berdasarkan hasil penelitian disimpulkan bahwa kinerja reproduksi kambing PE wilayah panatai secara umum hampir sama dengan wilayah pegunungan dan pengembangan secara besar-besaran untuk kambing PE di wilayah pantai sangat dianjurkan.
\end{abstract}

Kata kunci: perkawinan alami, inseminasi buatan, kambing PE, pantai, pegunungan

\section{Effect of Altitude on the Achievements of Artificial Insemination in Ettawa Crossbred Goats}

\begin{abstract}
This study was conducted to assess the reproductive performance and achievements of AI in goat reared in lowland and highland areas. The study used a survey method in two rural areas with the highest goat population. For lowland areas selected Karangwuni village while highland areas was Sidomulyo village. The results showed that for the lowland areas vs. the highland for reproductive performance were as follows: age of first estrus (10 vs $9.3 \mathrm{bl})$, age of first mating (13.2 vs $12.5 \mathrm{bl}$ ), mating system $100 \%$ natural, post partum mating (4.2 vs 4.6 months), $S$ / C (1.5 vs. 1.6). Understanding of farmers about the pregnant female: anestrus post-AI (85.7 vs. 22.2\%), stomach down (14.3 vs. 0.00), the condition of the udder (0.00 vs 77.8\%). Achievement results of AI (37.5 vs. $40 \%)$. Based on the results of the study concluded that the reproductive performance of goat in lowland areas was generally very similar to the highland areas, thus the development of large-scale goats in the lowland areas is recommended.
\end{abstract}

Key words: natural mating, artificial insemination, PE goats, lowland, highland 


\section{PENDAHULUAN}

Kambing Peranakan Ettawa (PE) banyak dipelihara oleh masyarakat Kulon Progo, yaitu di daerah dataran tinggi seperti di kecamatan Girimulyo, Samigaluh, Kokap dan di kecamatan Pengasih (desa Sidomulyo). Wilayah tersebut memang cocok untuk pengembangan kambing PE, disamping kambing PE menghendaki suhu rata-rata harian relatif rendah karena produksi susunya tinggi, juga lebih menyukai area dengan kontur dataran tinggi. Saat ini masyarakat yang tingga di dataran rendah juga mulai mengembangkan budidaya ternak kambing, karena melihat prospek dan potensi ternak kambing $\mathrm{PE}$ yang sangat menjajikan. Banyak masyarakat di pesisir pantai yang memelihara kambing, baik lokal (kacangan), bligon, sampai kambing PE. Pengembangan di daerah pantai merupakan alternative yang perlu dikaji baik produksi maupun reproduksinya. Umumnya permasalahan mutu genetik kambing PE yang berkualitas menjadi kendala utama pengembangan baik untuk daerah pegunungan maupun daerah pantai.

Wilayah Kulon Progo mempunyai garis wilayah pantai yang cukup panjang, yaitu sekitar $25 \mathrm{~km}$. Panjang garis pantai untuk Indonesia adalah $95.181 \mathrm{~km}$ dan merupakan urutan keempat di dunia setelah Amerika, Canada dan Rusia. Pemeliharaan ternak ini dilakukan salah satunya karena lahan pantai yang digunakan untuk usaha pertanian juga sebagai sumber hijauan pakan ternak, baik dari limbah pertanian maupun berasal dari tanaman pemecah angin seperti glirisidae, pohon waru dan tanaman perdu lainnya. Pekerjaan pokok sebagai nelayan sekarang bukan menjadi satu-satunya usaha untuk menghidupi keluarganya. Kendala utama pekerjaan nelayan adalah ketika terjadi perubahan cuaca seperti gelombang air yang tinggi sehingga tidak bisa melaut (Indra, 2009).

Wilayah pesisir pantai khususnya yang ada di kecamatan Wates menjadi pusat pencarian pakan rambanan dari masyarakat berbagai daerah. Produksi rambanan yang berasal dari tanaman pemecah angin sangat melimpah dan hijauan tersebut sangat cocok sebagai pakan kambing. Sehingga salah satu jenis ternak yang berkembang di daerah pantai adalah jenis kambing terutama kambing PE dan umumnya bligon. Penelitian ini bertujuan untuk mengetahui kinerja reproduksi dan capaian hasil IB kambing PE yang dipelihara di dataran tinggi (pegunungan) dan dataran rendah (wilayah pantai).

\section{MATERI DAN METODE}

Penelitian dilaksanakan pada bulan Februari sampai dengan Agustus tahun 2012, di desa Karangwuni (mewakili pantai) dan di desa Sidomulyo kecamatan Pengasih (mewakili pegunungan), Kabupaten Kulon Progo.

Materi penelitian ini adalah peternak yang di wilayah pantai, yaitu di Desa Karangwuni Kecamatan Wates dan Desa Sidomulyo Kecamatan Pengasih mewakili wilayah pegunungan. Ternak kambing PE betina yang sudah dewasa tubuh (umur minimal 10 bulan) dengan jumlah 30 ekor untuk kinerja reproduksi, sedangkan induk yang diinseminasi (inseminasi buatan/IB) 8 ekor di Karangwuni dan 10 ekor di Sidomulyo, pejantan kambing PE klas A yang berada di wilayah pegunungan Menoreh sebanyak 1 ekor. Pengencer sitrat kuning telur, PGF $2 \alpha$ untuk sinkronisasi birahi secara hormonal (IM, dosis 0,5 $\mathrm{ml} /$ ekor) digunakan dalam proses IB.

Metoda yang digunakan adalah metoda eksperimental dan survey terhadap calon/induk yang memenuhi syarat untuk di IB, yaitu sudah mencapai dewasa tubuh dan sedang tidak bunting (anestrus).

Penelitian diawali dengan observasi lapangan untuk menentukan jumlah induk kambing PE siap IB (calon induk minimal berumur 10 bulan dan sudah estrus), untuk masing-masing wilayah (pantai vs pegunungan) dan tidak sedang bunting.

Sinkronisasi dilakukan terhadap 18 ekor kambing betina dewasa menggunakan PGF $2 \alpha$ dengan dosis $0,5 \mathrm{ml} /$ ekor secara IM. 
Sinkronisasi dilakukan1 kali penyuntikan dan dilakukan pengamatan terhadap Angka Intensitas Birahi (AIB). Inseminasi Buatan dilakukan setelah muncul tanda-tanda birahi (48 jam setelah penyuntikan hormon). Inseminasi Buatan menggunakan semen segar pejantan PE unggul dengan dosis 200 juta sel/IB. Koleksi semen dilakukan beberapa kali hingga volume semen minimal diperoleh $2 \mathrm{ml}$ terhadap $1-2$ ekor pejantan unggul. Penampungan semen menggunakan vagina buatan, kemudian semen dilakukan uji kualitas makroskopis dan mikroskopis untuk mengetahui kualitas dan konsentrasinya. Pengenceran dilakukan menggunakan pengencer sitrat kuning telur dengan rasio $1 \mathrm{ml}$ semen menjadi $20 \mathrm{ml}$ campuran, dengan asumsi 4 milyar/ml maka dengan volume sebanyak itu dosis IB per ekornya minimal adalah 200 juta (15 ekorinduk) (Partodihardjo, 1987).

Inseminasi Buatan dilakukan dengan metode cervical yaitu mendeposisikan semen melalui cerviks (Toelihere, 1993). Pengamatan keberhasilan IB dilakukan pada 90 hari pasca IB dengan cara mengamati kembalinya birahi pada waktu siklus birahi yang seharusnya (NR-90).

Data yang diamati meliputi kinerja reproduksi induk/calon kambing $\mathrm{PE}$ terutama data dasar calon induk / induk meliputi data umur pertama estrus, umur kawin pertama, post partum estrous (PPE), $\mathrm{S} / \mathrm{C}$, pemahaman peternak terhadap betina bunting, hasil IB pada hari ke 90 untuk 2 wilayah yang berbeda. Data yang diperoleh untuk identitas peternak, ukuran tubuh, umur ternak dan capaian hasil IB dianalisis secara diskriptif.

\section{HASIIL DAN PEMBAHASAN}

\section{Umur Pertama Estrus}

Kinerja reproduksi kambing $\mathrm{PE}$ di wilayah pantai dan pegunungan tertera pada Tabel 1. Berdasarkan hasil penelitian umur pertama estrus kambing PE wilayah pantai adalah 10 bulan, sedangkan untuk wilayah pegunungan 9,54 bulan. Kondisi ini masih normal, sebagaimana dijelaskan bahwa kisaran umur estrus pertama bagi kambing PE adalah 8 - 10 bulan (Utomo, 2011). Kondisi pakan wilayah pantai dan pegunungan relatif sama baik dalam kuantitas maupun kualitasnya, sesuai penelitian Rasminati (2011) yang menyatakan bahwa potensi pakan wilayah pantai tersedia hijauan berupa rambanan yang melimpah demikian juga untuk yang ada di wilayah pegunungan, perbedaan terjadi pada variasi jenis hijauannya saja oleh karena model pemberian pakan karena kontur wilayah. Disamping itu juga strain kambing PE antara wilayah pantai dengan wilayah pegunungan (16,7\% vs $50 \%)$.

Umur pertama estrus untuk kambing PE berkisar antara 6 - 10 bulan sebagaimana Syukur (2006) yang menyatakan bahwa kambing mencapai dewasa kelamin pada umur $6 \mathrm{~s} / \mathrm{d} 10$ bulan, dan dikawinkan pada umur 10-12 bulan atau saat bobot badan mencapai 55 - 60 kg. Sarwono (1999) menyatakan bahwa umur pertama pubertas kambing PE di Turi dicapai pada umur $6-8$ bulan, namun peternak di Turi mengawinkan pertama kambing PE rata-rata umur 15 bulan (Suranindyah, et al., 2009).

Umur, berat badan dan kondisi tubuh berpengaruh terhadap tercapainya pubertas. Ternak yang tumbuh lebih cepat akan mencapai pubertas lebih awal. Pada kambing pubertas dicapai pada umur bervariasi $6-12$ bulan atau pada berat sekitar $55-60 \%$ berat badan dewasa (Sutama et al., 1995). Umur pubertas erat kaitannya dengan kondisi pakan yang dikonsumsi.

\section{Umur Pertama Kawin}

Hasil penelitian umur pertama kawin untuk kambing PE yang dipelihara di wilayah pantai vs gunung adalah 13,2 vs 12,5 bulan. Menurut Suranindyah (2009) pada bangsa kambing PE kelas besar umur pertama kawin biasanya mencapai 15 bulan sehingga beranak pertama dicapai umur 20 bulan, penundaan waktu kawin pertama tersebut semata-mata mempertimbangkan berat badan maksimum dan kematangan 
Tabel 1. Rata-rata kinerja reproduksi kambing PE wilayah pantai vs gunung

\begin{tabular}{lcc}
\hline Parameter & Pantai & Gunung \\
\hline Umur pertama estrus (bl) & 10 & 9,54 \\
Umur pertama kawin (bl) & 13,2 & 12,5 \\
Kidding Interval (bl) & 9,3 & 9,5 \\
Cara kawin & & \\
$\quad$ Kawin alam (\%) & 100 & 100 \\
$\quad$ IB & 0 & 0 \\
Post Partum Matting (bl) & 4,2 & 4,6 \\
S/C (kali) & 1,5 & 1,6 \\
Pemahaman betina bunting (\%) & & \\
$\quad$ Anestrus pasca IB & 85,7 & 22,2 \\
$\quad$ Perut turun & 14,3 & 0,00 \\
$\quad$ Kondisi puting susu & 0,00 & 77,8 \\
\hline
\end{tabular}

tubuh (dewasa tubuh) khususnya untuk bangsa Ettawa murni umur pertama kawin mencapai 18 bulan dan beranak pertama sampai 23 bulan.

Perbedaan secara rata-rata untuk umur pertama kawin pantai vs gunung disebabkan oleh banyak faktor. Faktor tersebut diantaranya adalah kualitas peternak terhadap pemahaman kambing estrus, ketersediaan pejantan yang diinginkan, kualitas manajemen khususnya manajemen reproduksi, kondisi pakan, kondisi calon induk/induk yang akan dikawinkan dan kesempatan peternak untuk mengawinkannya. Wilayah pantai dengan pengalaman beternak kambing PE yang ratarata baru 2,9 tahun akan sangat berbeda pemahamannya dengan pengalaman beternak kambing PE di wilayah pegunungan yang rata-rata 9 tahun. Faktor lain seperti kondisi pakan diduga memiliki kualitas yang relatif sama, serta adanya perbedaan strain antara bligon $(66,7 \%$ di pantai) dengan strain PE $(50 \%)$ di pegunungan.

Peternak kambing PE di wilayah pantai maupun pegunungan mengawinkan untuk pertama kalinya jauh lebih cepat dibandingkan dengan hasil penelitian Suranindyah (2009) di wilayah Turi menunjukan bahwa kawin pertama kambing $\mathrm{PE}$ adalah $14.9 \pm 4.1$ bulan. Mereka beralasan kawin pertama tetap memperhatikan bobot badan agar dihasilkan keturunan yang baik.

\section{Jarak beranak (Kidding Interval )}

Kidding interval kambing PE yang dipelihara di wilayah pantai vs pegunungan adalah 9,3 bulan vs 9,5 bulan masih masuk dalam kisaran normal. Rout et al. (2002) menyatakan bahwa kidding interval bisa mencapai 11 bulan, dengan umur pertama bunting 18 bulan dan pertama beranak 23 bulan untuk kambing Ettawa. Suranindyah (2009) menyatakan bahwa kidding interval kambing PE di wilayah Turi adalah 10,0土 3,3 bulan.

Interval diantara dua kelahiran dan post partum estrous yang pertama memberikan kontribusi yang sangat penting bagi efisiensi reproduksi (Greyling, 2000). Kidding interval dan lama bunting dipengaruhi oleh faktor genetik, lingkungan dan manajemen (Urdaneta et al., 2000). Kidding interval dipengaruhi oleh post partum estrous, S/C dan lama bunting (Utomo, 2011). Berdasarkan kisaran bulan, kidding interval antara wilayah pantai dengan pegunungan relatif sama dan masih dalam kisaran normal.

Kidding interval ditentukan oleh lama kebuntingan dan waktu birahi setelah beranak. Variasi lama kebuntingan pada kambing relatif kecil yaitu $144-156$ hari 
(Sutama, 1996; Artiningsih et al., 1996; Adiati, et al., 1999; Kostaman dan Sutama, 2006). Tiga sampai lima bulan setelah beranak, ternak umumnya akan birahi kembali sehingga selang beranak antara 8 10 bulan. Di tingkat lapangan selang beranak dapat mencapai lebih dari 12 bulan. Hal ini sering disebabkan oleh karena tidak terdeteksinya birahi dan petani tidak memiliki pejantan. Padahal, penentuan birahi pada kambing lebih sulit tanpa adanya pejantan (Sutama et al., 1993).

Odubote's (2000) menyatakan bahwa kidding interval kambing West African Dwarf dipengaruhi secara nyata oleh faktor keturunan dan musim dengan rata-rata kidding interval 275,68 \pm 6,08 hari (sekitar 9,2 bulan) dengan rentang waktu kidding interval $187 \mathrm{~s} / \mathrm{d} 478$ hari.

Kidding interval minimum 205 hari $(6,8$ bln $)$ untuk kambing kacang dan maksimum 450 hari (15 bln). Untuk kambing PE berkisar antara 240 hari $(8 \mathrm{bln})$ lebih pendek dari rata-rata kidding interval kambing kacang. Hal ini disebabkan karena perbedaan services period dan periode kebuntingan. Services period dipengaruhi oleh fertilitas kambing dan pengelolaan pembibitan dari peternaknya.

Interval kelahiran hasil penelitian Murdjito et al.(2011) rata-rata 8,53 bulan dengan kisaran $7-12$ bulan. Menurut. Prayitno (2003) kambing bligon memiliki interval kelahirann 10,3 - 10,7 bulan. Sedangkan menurut Rustadi (2008) kambing $\mathrm{PE} /$ bligon memiliki interval kelahiran 8,33 dan 8,20 bulan. Hasil penelitian kambing PE dan Bligon di kedua wilayah penelitian masih masuk dalam kisaran waktu normal.

\section{Cara Kawin}

Umumnya peternak kambing PE mengawinkan ternaknya secara alami. Data penelitian menunjukan bahwa kawin alam merupakan satu-satunya cara kawin yang selama ini dilakukan peternak kambing PE. Secara umum kawin secara alami memiliki tingkat keberhasilan hampir 100\% (Utomo,S., 2011). Kawin alam sering ditemukan dalam kehidupan liar, perkawinan berkelompok seperti banyak ditemukan pada perkawinan domba namun kambing PE meskipun dilakukan secara alami namun tetap dikontrol oleh manusia dalam penentuan pasangannya dan waktu kawinnya (Feradis, 2010).

Cara untuk mendapatkan angka kebuntingan yang tinggi adalah dengan sistem kawin alam. Rasio antara jantan dan betina dalam perkawinan alami ini dapat 1:10 - 1:50 ekor, bahkan dengan manajemen perkawinan yang baik, jumlah induk betina dapat ditingkatkan. Di daerah tropis, siklus birahi pada kambing dapat terjadi sepanjang tahun, sesuai dengan ritme reproduksinya asalkan kondisi tubuh ternak mendukung terjadinya proses reproduksi (WodzickaTomaszewska et al., 1991; Sutama, 2009; Sutama, 2011; Sutama et al., 1993).

Manfaat kawin alam adalah performan pejantan kualitas/gradenya dapat secara langsung diketahui dan umumnya perkawinan alam tingkat keberhasilannya tinggi (data $\mathrm{S} / \mathrm{C}$ pantai vs gunung adalah 1,5 vs 1,625$)$. Hal itu diduga disebabkan karena kesiapan betina untuk menerima perkawinan (berhubungan dengan puncak birahi/standing heat) sehingga menghasilkan perkawinan lebih dari 1 kali untuk terjadinya kebuntingan.

Dampak kawin secara IB adalah menuntut pelaksanaan secara bersama-sama melalui sinkronisasi birahi agar terjadi peningkatan efisiensi sebagaimana disebutkan Sutama (2011) bahwa banyaknya kambing yang birahi dan kawin secara serempak maka manajemen pemeliharaan akan lebih mudah dilakukan dan lebih efisien. Di samping itu jumlah anak yang lahir dalam satuan waktu meningkat dan pada akhirnya pendapatan petani meningkat.

\section{Post Partum Mating (PPM)}

Hasil penelitian menunjukkan pemeliharaan kambing PE baik di wilayah pantai vs pegunungan memiliki post partum mating (PPM) 4,2 bulan vs 4,6 bulan. Kondisi ini lebih panjang jika dibandingkan 
dengan pernyataan Syukur (2006) bahwa bunting kembali setelah beranak adalah 2 bulan. Dalam hitungan bulan angka tersebut relatif sama meskipun secara kecenderungan post partum mating (PPM) wilayah pantai lebih baik. Kondisi pakan wilayah pantai dengan pegunungan disaat penelitian dilakukan relatif sama, baik dari segi kuantitas maupun kualitasnya. Meskipun secara fisik, ketersediaan glirisidae di wilayah pantai jauh lebih banyak $(50 \%$ glirisidae), pegunungan terbanyak untuk daun ketela pohon dan glirisidea hanya $25 \%$ (Rasminati, 2011).

Hasil penelitian terhadap PPM kambing PE dan Bligon di kedua wilayah masih masuk dalam kisaran normal, sebagaimana telah diteliti pada kambing Bligon di wilayah Gunungkidul yang memiliki PPM 45 - 180 hari dengan ratarata 95 hari (Murdjito et al., 2011) dan 122 hari pada kambing Bligon (Rustadi, 2008). PPM menunjukkan kemampuan seekor induk untuk timbulnya keinginan kawin setelah beranak. PPM menjadi indikator manajemen reproduksi yang baik. Hal ini disebabkan karena PPM dipengaruhi oleh perawatan induk setelah melahirkan khususnya yang berkaitan dengan kecukupan pakan dan kesempurnaan gizinya.

\section{Service per conception (S/C)}

Hasil penelitian menunjukkan $\mathrm{S} / \mathrm{C}$ kawin alam wilayah pantai vs pegunungan adalah 1,5 vs 1,625 kali. Data ini menunjukan angka yang relatif lebih rendah jika dibandingkan Feradis (2010). Selanjutnya dinyatakan bahwa $\mathrm{S} / \mathrm{C}$ berkisar antar 1,6-2,0, makin rendah $\mathrm{S} / \mathrm{C}$ maka semakin tinggi kesuburan ternak tersebut, sebaliknya semakin tinggi nilai $\mathrm{S} / \mathrm{C}$ berarti semakin rendah nilai kesuburan ternak tersebut.

Peternak di wilayah pantai memiliki $\mathrm{S} / \mathrm{C}$ relatif lebih baik dibandingkan dengan wilayah pegunungan hal ini disebabkan peternak wilayah pantai memiliki curahan waktu dan perhatian relatif lebih tinggi dibandingkan dengan peternak di wilayah pegunungan. Sebagai usaha pokok $(100 \%)$ di wilayah pantai akan lebih tinggi perhatiannya dibandingkan sebagai usaha sambilan untuk tujuan tabungan $(87,5 \%$ usaha pokok di pegunungan). Rerata S/C kambing bligon yang dipelihara di peternak Gunungkidul adalah 1-2 kali (Murdjito et al., 2011) dan 1,59 kali (Rustadi, 2008).

\section{Capaian Hasil IB}

Hasil sinkronisasi pada penelitian ini menunjukan kambing dengan angka intensitas birahi baik hanya $60 \%$ di pantai dan $80 \%$ di pegunungan. Seperti dilaporkan bahwa sinkronisasi birahi dan ovulasi secara hormonal menggunakan PGF2 $\alpha$ (prostaglandin analog) atau progesteron sinthetis, dan diperoleh persentase birahi secara serempak mencapai $80-100 \%$ (Artiningsih et al., 1996; Adiati, et al., 1999; Sutama et al., 2002a)

Penentuan kebuntingan berdasarkan angka NR (Non Return= tidak kembali birahi) 90 hari. NR adalah suatu ukuran yang umum dipakai dalam istilah kebutingan (Feradis, 2010). Angka 90 menunjukan bahwa sampai dengan 90 hari pasca IB ternak tidak kembali minta kawin (estrus). Data hasil penelitian selengkapnya pada Tabel 2.

Jumlah induk bunting kambing PE hasil IB pada NR-90 antara wilayah pantai dengan pegunungan adalah $(37,5 \%$ vs $40 \%$ ). Wilayah pegunungan memiliki angka CR (Conception Rate) lebih tinggi dibandingkan dengan wilayah pantai, hal ini disebabkan karena beberapa faktor. Faktor yang berhubungan dengan hasil IB meliputi kualitas semen/pejantan, kondisi induk khususnya AIB (angka intensitas birahi) dan ketrampilan inseminator serta peternaknya itu sendiri. AIB wilayah pantai lebih rendah dibandingkan dengan AIB wilayah pegunungan ( $60 \%$ vs $80 \%)$.

Masyarakat pegunungan jauh lebih paham terhadap reproduksi ternak dan kebiasaan-kebiasaan ternak, disebabkan karena lamanya pengalaman beternak. 
Tabel 2. Capaian hasil IB kambing PE berdasarkan NR-90 di wilayah pantai vs pegunungan

\begin{tabular}{lcc}
\hline Parameter & Pantai & Pegunungan \\
\hline Jumlah yang di IB & 8 ekor & 10 ekor \\
Bunting (NR 90) & 3 ekor $(37,5 \%)$ & 4 ekor $(40 \%)$ \\
\hline
\end{tabular}

Meskipun perbedaan hasil IB pada NR-90 juga tidak begitu besar. Perbedaan NR-90 wilayah pegunungan dengan pantai diduga juga karena perbedaan ketinggian tempat yang akan banyak berpengaruh terhadap pola makan, kualitas vegetasi, kecepatan angin yang pada akhirnya tingkat stres ternak yang akan berakibat terjadinya perbedaan produktifitas. Adanya pengaruh faktor lingkungan terhadap penampilan reproduksi ternak (Awemu et al., 1999 dan Urdaneta et al., 2000).

Di samping itu, ternak kadangkadang tidak menunjukkan tanda birahi dengan jelas, walaupun secara fisiologis dalam keadaan birahi (Silent heat). Hal ini disebabkan tidak adanya hormon progesteron yang cukup tinggi untuk menstimulir peningkatan sekresi hormon estrogen yang diperlukan untuk terjadinya ekspresi birahi (Foster dan Ryan, 1981; Sutama et al., 1988c; Sutama, 2011).

Rendahnya angka kebuntingan di kedua wilayah (pantai dan gunung) disebabkan oleh teknis Inseminasi yang hanya dilakukan 1 kali saja. Sedangkan menurut Sutama (2011) pada perkawinan alami secara dituntun (hand mating) atau secara inseminasi buatan (IB), perkawinan/inseminasi dilakukan pada setengah bagian akhir masa birahi dan diulang setelah 10-12 jam (Sutama, 2011).

Hasil penelitian hasil IB wilayah pantai sebesar $37,5 \%$ dan wilayah pegunungan sebesar $40 \%$ masih lebih tinggi jika dibandingkan penelitian sebelumnya sebagaimana disebutkan bahwa kesulitan dalam melakukan deposisi semen intrauterine merupakan salah satu kendala IB pada kambing. Servik kambing yang berkelok-kelok (berbentuk spiral) menyulitkan alat inseminasi (insemination gun) dapat masuk sampai ke uterus. Umumnya deposisi semen hanya dapat dilakukan diluar servik atau dalam vagina sehingga tingkat kebuntingan yang diperoleh masih rendah yaitu sekitar 30\% (Budiarsana dan Sutama, 2001; Sutama et al., 2002 ${ }^{\text {b }}$; Ngangi, 2002; Sutama, 2011). Pemanfaatan teknologi inseminasi buatan (IB) mempunyai kontribusi yang cukup besar dalam meningkatkan produktivitas ternak dan efisiensi usaha, terutama dalam memanfaatkan pejantan unggul, dan menurunkan biaya pemeliharaan pejantan (Sutama, 2011).

\section{KESIMPULAN}

Manajemen reproduksi kambing PE yang dipelihara oleh masyarakat wilayah pantai secara umum sama dengan wilayah pegunungan. Capaian hasil IB wilayah pantai dan pegunungan relatif sama, yaitu sebesar $37,5 \%$ di wilayah pantai dan $40 \%$ di wilayah pegunungan. Pengembangan kambing PE sebagai upaya pemberdayaan masyarakat dan potensi sumber daya alamnya bisa dikembangkan di wilayah pantai, berdasarkan kesamaan kinerja reproduksinya.

\section{DAFTAR PUSTAKA}

Adiati, U., D. Yulistiani, R. S.G. Sianturi, Hastonodan I.G.M. Budiarsana, 1999. Pengaruh perbaikan pakan terhadap respon reproduksi induk kambing Peranakan Etawah. Prosiding Seminar Nasional Peternakan dan Veteriner, Bogor: 491-495.

Artiningsih, N.M, B Purwantara, R.K. Achjadi dan I.K. Sutama. 1996. Pengaruh Penyuntikan Pregnan Mare' Serum Gonadhotropin terhadap Kelahiran Kembar pada kambing Peranakan Ettawah. Jurnal Ilmu Ternak dan Veteriner 2(1): $11-16$.

Awemu, E.M., L.N. Nwakolar, B.Y. Abubakar, (1999): Environmental influences on preweaning mortality and reproductive 
performance of Red Sakoto does. Small Ruminant Research. 34: 161-165.

Budiarsana, IGM. dan I.K. Sutama. 2001. Fertilitas Kambing Peranakan Ettawah pada Perkawinan Alami dan Inseminasi Buatan. Prosiding Seminar Nasional Peternakan dan Veteriner. Pusat penelitian dan Pengembangan Peternakan Bogor: 85-95.

Feradis, 2010. Bioteknologi Reproduksi pada Ternak. Penerbit ALFABETA, Bandung.

Foster, A.E. dan K.D. Ryan. 1981. Endocrine Mecanism Governing Transition in to Adolt Hood in Female Sheep. J. Reprod. Fert. (Supplemen 30): 75 - 90.

Greyling, J.P.C., 2000. Reproduction Traits in the Boer goats doe. Small Ruminant Research. 36: 171-177.

Indra, 2009. Panjang Garis Pantai Indonesia Terbaru http://seputarberita .blogspot. com /2009 / 03/ panjang-garis-pantai-indonesiaterbaru.html. (24-01-2011).

Kostaman,T. Dan I.K. Sutama. 2006. Studi Motilitas dan daya Hidup Spermatozoa Kambing Boer pada Pengencer Tri-SitratFruktose. Jurnal Sain Veteriner, 24: 58-64.

Murdjito, G., I. G. S. Budisatria, Panjono, N. Ngadiyono, dan E. Baliarti, 2011. Kinerja Kambing Bligon yang Dipelihara Peternak di Desa Giri Sekar, Panggang, Gunung Kidul. Buletin Peternakan, 35(2): 86-95.

Odubote, I.K., 2000. Genetic Analysis of Reproductive Performance of West African Dwarf Goats in the Humid Tropics. Proceeding of the First Bienneal Conference of the African Small Ruminant Research Network, ILRAD. Nairobi, Kenya, 10-14 December 1990. (www.fao.org/wairdocs/ilri/x 5473b/x/5473b 09.htm\#

Odubote, I.K., 1996. Genetic parameters for littersize at birth and kidding inerval in the West African Dwarf Goats. Small Ruminant Research. 20: 261-265.

Partodihadjo, S., 1987. Ilmu Reproduksi Hewan. Fakultas Kedokteran Veteriner, IPB. Bogor.

Prayitno, W. 2003. Kinerja induk kambing Bligon di Kecamatan Kretek dan Piyungan, Kabupaten Bantul, Daerah Istimewa Yogyakarta. Skripsi Sarjana Peternakan. Fakultas Peternakan, Universitas Gadjah Mada, Yogyakarta.

Rasminati, N., 2011. Potensi Wilayah Pesisir Pantai Kecamatan Wates untuk Pengembangan Kambing Peranakan Etawah di Kulon Progo. Laporan Penelitian. Universitas Mercu Buana Yogyakarta.

Rout, P. K., A. Mandal, M. K. Singh, R.Roy, N. Sharma and G.F.W. Haenlein.2002. Jamunapari a Dairy Goat Breed inIndia, accessed 16 January 2002.

Rustadi, A.M. 2008. Kinerja induk kambing Bligon di Kecamatan Jogonalan Kabupaten Klaten Jawa Tengah. Skripsi Sarjana Peternakan. Fakultas Peternakan, Universitas Gadjah Mada, Yoyakarta.

Sarwono, B. 1999. Beternak KambingUnggul. Penebar Swadaya. Jakarta.

Sutama, IK., I.G. Putu N. M. W. Tomanszewska, 1993. Small Ruminant Production in Humid Tropics : Improving small ruminant productivity through efficiency of reproduction character. Sebelasmaret University Press, Surakarta, Indonesia.

Sutama, IK., I.G.M. Budiarsana and Y. Saefudin, 1995. Kinerja reproduksi sekitar pubertas dan beranak pertama kambing Peranakan Etawah. Jurnal Ilmu dan Peternakan 8 (1) 9-12.

Sutama, IK., 1996. Potensi Produktivitas ternak Kambing di Indonesia. Prosiding Seminar nasional Peternakan dan Veteriner. Pusat penelitian dan Pengembangan Peternakan, Bogor. Hlm. 35-50.

Sutama,IK., R. Dharsana, IGM. Budiarsana, dan T. Kostaman, 2002 ${ }^{\mathrm{a}}$. Sinkronisasi Birahi dengan Larutan Komposit Testosteron, Estradiol dan Progesteron (TOP) pada kambing Peranakan Ettawah. Jurnal Ilmu Ternak dan Veteriner $7:$ 110-115.

Sutama,IK., B. Setyadi, P. Z. Situmorang, U. Adiati, IGM. Budiarsana, T. Kostaman, Maulana, Mulyawan, dan R. Sukmana. $2002^{\mathrm{b}}$. Uji Kualitas Semen Beku Kambing Peranakan Ettawah dan kambing Boer.. Prosiding Hasil Penelitian Bagian Proyek Rekayasa Teknologi Peternakan/ARMP-II. Pusat penelitian dan Pengembangan Peternakan Bogor. Hlm. 88-111.

Sutama, 2011. Inovasi Teknologi Reproduksi Mendukung Pengembangan Kambing Perah Lokal. Pengembangan Inovasi Pertanian 4 (3) 2011:231-246.

Syukur, D.A., 2006.http://disnakkeswanlampung.go.id/brosur/kambing.pdf

Suranindyah,Y., T.S.M. Widi, Sumadi, N. H. Tarmawati, and U. Dwisepta, 2009. Production performance of Ettawah Crossbreed goat in Turi Sleman 
Jogjakarta.The 1st International Seminar on Animal IndustryBogor: 314-318.

Toelihere, M., 1993. Inseminasi Buatan pada Ternak. Angkasa. Bandung.

Urdaneta, L.D.,G.T.Hernandez, C.M.B.Perez, O.G. Betancourt, F.G. Cossio, M.O. Arce and O.G. Betancourt, 2000. Comparison of Alpine and Nubian Goats for some reproductive traits under dry tropical condition. Small Rum. Res. 36: 91-95.
Utomo, S., 2011. Produktivitas Kambing PE di Wilayah Pengembangan Pesisir Pantai Kecamatan Wates, Kulon Progo. Laporan Penelitian. Universitas Mercu Buana Yogyakarta.

Utomo,S., 2013. Perbedaan ketinggian tempat terhadap capaian hasil IB pada kambing Peranakan Ettawah (PE). Laporan Penelitian. Universitas Mercu Buana Yogyakarta. 